\title{
A Distributional Analysis of the Socio-Ecological and Economic Determinants of Forest Carbon Stocks
}

\author{
José R. Soto $^{1}$, Francisco J. Escobedo ${ }^{2}$, Damian C. Adams ${ }^{3}$, German Blanco ${ }^{4}$ \\ ${ }^{1}$ School of Forest Resources and Conservation, University of Florida, P.O. Box 110410, \\ Gainesville, FL 32611, USA; E-Mail: josesoto@ufl.edu *Corresponding Author \\ ${ }^{2}$ Functional and Ecosystem Ecology Unit (EFE) Biology Program, Faculty of Natural \\ Sciences and Mathematics, Universidad del Rosario Kr 26 No 63B-48, Bogotá D.C., \\ Colombia; franciscoj.escobedo@urosario.edu.co \\ ${ }^{3}$ School of Forest Resources and Conservation, University of Florida, P.O. Box 110410, \\ Gainesville, FL 32611, USA; E-Mail: dcadams@ ufl.edu \\ ${ }^{4}$ Economics Department, Illinois State University. Campus Box 4200, Normal, IL 61790, \\ USA; E-Mail: gblanco@ilstu.edu
}




\begin{abstract}
Forest carbon (C) sequestration is being actively considered by several states as a way to costeffectively comply with the forthcoming United States (US) Environmental Protection Agency rule that will reduce power plant C emissions by $32 \%$ of 2005 levels by 2030. However, little is known about the socioecological and distributional effects of such a policy. Given that $\mathrm{C}$ is heterogeneous across the landscape, understanding how social, economic, and ecological changes affect forest $\mathrm{C}$ stocks and sequestration is key for developing forest management policies that offset $\mathrm{C}$ emissions. Using Florida as a case study, we use US National Forest Inventory Analysis and Census Bureau data in both linear regression and quantile regression analyses to examine the socio-ecological and economic determinants of forest $\mathrm{C}$ stocks and relationship with differing communities. Quantile regression findings demonstrate nonlinearity in the effects of key determinants, which highlight the limitations of regularly used mean-based regression analyses. We also found that forest basal area, site quality, stand size, and stand age are significant ecological predictors of carbon stocks, with a positive and increasing effect on upper quantiles where $\mathrm{C}$ stocks are greater. The effect of education was generally positive and mostly significant at upper quantiles, while the effects of income and locations with predominantly minority residents (as compared to whites) were negative. Upper quantiles were also affected by population age. Our findings underscore the importance of considering the broader socioecological implications of compliance strategies that target the management of forests for carbon sequestration and other ecosystem services.
\end{abstract}

Keywords: Carbon Sequestration; Distributional Impacts; Quantile Regression; Forest Inventory and Analysis; Ecosystem Services 


\section{Introduction and Background}

Under the 2014 Clean Power Plant (CPP) rule proposed by the United States (US) Environmental Protection Agency (EPA), states must collectively reduce carbon (C) emissions from coal-fired power plants by $32 \%$ of 2005 levels by 2030 , with state-specific targets defined by historic emissions and other factors (EPA, 2015). As part of these emissions reduction targets, the EPA has indicated that states will have flexibility in developing emissions compliance portfolios that best fit their needs. Importantly for forest landowners, the EPA has explicitly stated that $\mathrm{C}$ sequestration from forestry and agriculture may be included in these portfolios, and that the new policy will reinforce existing regional greenhouse gas programs such as the Regional Greenhouse Gas Initiative (RGGI), California's "Global Warming Solutions Act" (AB32), and Colorado's "Clean Air, Clean Jobs Act" all of which include forest $\mathrm{C}$ offsets.

Collectively, US forests have tremendous potential to offset $\mathrm{C}$ emissions, likely accounting for $15 \%\left(979.3 \mathrm{TgCO}_{2}\right)$ of total US emissions reductions (EPA, 2014). Several regional and national studies have found that using forests to capture Greenhouse Gas (GHG) emissions merits serious consideration from both policy makers and landowners (e.g., Adams et al., 1999; Lubowski et al., 2005; Qureshi et al., 2011) given the expected marginal costs of forest $C$ sequestration relative to other C emissions reduction approaches (Charnley et al., 2006). Indeed, forest-based C sequestration is considered an important, relatively low cost approach to mitigating $\mathrm{C}$ emissions (Pacala and Socolow, 2004; Parks and Hardie, 1995; Adams et al., 1999; Nielsen et al., 2014; Markowski-Lindsay et al., 2011; Stavins, 1999; Richards and Stokes, 2004; Escobedo et al., 2010).

Currently, forests cover approximately one third of all U.S. land area (Smith et al., 2009), largely concentrated in several southern, northeastern, and northwestern states. Given their share of total land area in these states, even small changes in forest policy or forest product markets can affect regional economies and community dynamics. Forests in the southeastern US are being lost however, due to development, socio-economic changes, increasing land values, and climate change in the form of disturbance (Brown and Nowack, 2010). 
Managing forests for $\mathrm{C}$ requires information on ecological disturbance regimes, stand

characteristics, species diversity, and other influential drivers (Wardle and others 2003, Luyssaert and others 2008). Recent studies have identified areas in the state of Florida with high forest C stocks, or hotspots, (Timilsina et al., 2013; Cademus et al. 2014) and several influential determinants including: forest type, site quality, stand age, location in periurban and conservation areas, and silvicultural treatments. Other factors known to drive $\mathrm{C}$ stocks include disturbance regimes and species diversity (Wardle and others 2003, Luyssaert and others 2008). Changes in forest management can subsequently have significant impacts on the communities where these forests grow (Jindal et al., 2008; Caplow et al., 2011), raising serious concerns about the social, economic, and ecological aspects of forest C sequestration projects (Brown and Corbera, 2003).

Studies have also analyzed landowner and socioeconomic characteristics associated with particular forest management practices and related ecosystem services (Beach et al., 2005; Joshi and Arano, 2009; Fischer and Charnley, 2010; Kaetzel et al., 2012; Miller et al., 2012; Szantoi et al., 2012; Stein et al., 2014). Joshi and Arano (2009) for example identified the demographic, tenure and forest stand characteristics that influence forest management characteristics. In their reviews, Beach et al. (2005) and Fischer and Charnley (2010) found that income, education, age, owner proximity as well as forest site quality, growing stock and plot size have been found to affect forest management behavior.

However, despite the need for such research, very little emphasis has been placed on identifying the socio-ecological and economic factors that affect forest $\mathrm{C}$ stocks, or understanding the impacts that $\mathrm{C}$ sequestration policy changes will have on communities. As lawmakers develop programs to achieve $\mathrm{C}$ emissions reductions, it is important to consider the broad socio-ecological context of increasing forest $\mathrm{C}$ sequestration, to ensure that forest $\mathrm{C}$ policy choices align with more traditional economic and social development goals (e.g., ecosystem services, environmental justice, voter referendums).

In this study, we econometrically assess the potential distributional effects of important socioecological and economic determinants of forest $\mathrm{C}$ stocks in Florida US. We employ socio-economic 
data from the U.S. Census and plot-level ecological data from the National Forest Inventory Analysis

program in both linear regression and quantile regression (e.g. Damette and Delacote, 2012) models to predict the socio-ecological and economic determinants of forest $\mathrm{C}$ stocks along a C-poor to C-rich gradient.

\section{Materials and Methods}

\subsection{Study Area}

Florida is one of the fastest growing states in the US with a highly urbanized population of 19.9 million residents (Smith et al. 2011). The state grew by nearly 2.8 million residents between 2000 and 2010, with sixteen counties doubling in size during this period. Despite this, Florida is also heavily forested, with forests comprising approximately half of the state's land area and more than half of the counties are over $50 \%$ forested, and forest area growing by $2.63 \%$ from 2007-2010 (Brown and Nowack, 2010). Under the proposed EPA Clean Power Plant rule, Florida will need to cut roughly $26 \%$ of 2012 power plant $\mathrm{CO}_{2}$ emissions by 2030 (EPA, 2015). Given the state's forest resources, forest $\mathrm{C}$ sequestration can likely play a strong role in the state's emissions reduction portfolio.

Florida has a mean annual temperatures range from $16-25^{\circ} \mathrm{C}$ and mean annual precipitation ranges of 1000-1600 mm (McNab and Avers 1994). The USDA Forest Service's Ecoregions in Florida include coastal flatwoods, coastal plains, eastern and western coastal lowlands, and the everglades in the extreme southern portion of the state (Bailey 1995), and there are over 20 forest types in Florida ranging from temperate pine-oak lands to tropical hardwoods (Figure 1; Woudenberg et al. 2010). Roughly $92 \%$ of forested area is classified as timberland and $65 \%$ of this timberland area is owned by nonindustrial private forest owners and 30\% is publically owned (Brown and Nowak, 2012). 


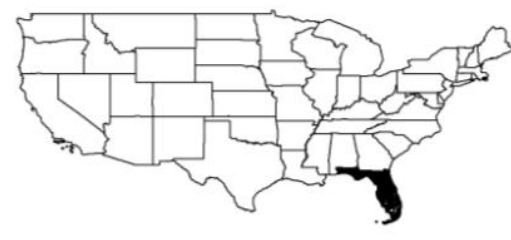

\subsection{Data Sources and Description}

We used the U.S. Department of Agriculture (USDA) National Forest Inventory Analysis (FIA) data at the plot-level, which includes data on forest management and ecological variables. See Woudenberg et al., (2014) for specific details. The FIA data have been used to spatially analyze regional forest management and carbon stock characteristics (Cademus et al., 2014; Delphin et al., 2014; Timilsina et al., 2012); and studies have coupled these data with US Census Bureau data to characterize forest owner and tenure characteristics (Kaetzel et al 2012; Szantoi et al 2012), and to inform regional forest-landowner studies (e.g., Butler and Leatherberry 2004). Census data have also been previously used to identify correlates of forest- $\mathrm{C}$ management characteristics and owner behavior in private rural and urban lands (Beach et al. 2005; Fischer and Charnley 2010; Joshi and Arano 2009; 
Szantoi et al 2012). Most FIA data does not include the true plot locations because of privacy protections (Woudenberg et al., 2012).

The FIA data were matched at the US Census block level, the smallest unit of the Census data, to investigate the relative importance of the spatially matched socioeconomic and ecological factors that potentially influence the conservation and/or enhancement of forest $\mathrm{C}$ stocks in the State of Florida. To approximate the true FIA plot location, we used Delphin et al.'s (2013) method that uses FIA database attributes (e.g. FIA Survey Unit, ecological subsection, county, condition status, and stand age) to better locate the plots according to unique combination of forest type, ecological subsection and county. Geospatial plot-level forest inventory data from the FIA Cycle 9 (2009 to 2011; Table 1) observations were then merged with 2010 Census Blocks for the State of Florida and the 2010 5 year American Community Survey Census tracts (Table 2). The three datasets were merged using their respective FIA geographic identification codes (GEOID, GEOID10 field). The unit of observation is the Census block, which is generally defined to contain between 600 and 3,000 people. The majority of the data was available at the Census block level, except for Income, Education, and Owner Occupied, which were only available in Census tracts, a more aggregate observation of the latter. The FIA GEOID10 code was disaggregated to the Census block level and merged with the Census and ACS data. The Census data, which also contained Census block level observations, were merged using the FIA GEOID10 code column. The ACS spreadsheet, which contained Census tract level data, was also aligned with the FIA Census tract GEOID10 code (an 11 digit subset of the 12 digit GEOID10 code). Given the disaggregate-data limitation of ACS, the Census plots in the ACS Census tracts were assumed to be the same, and so each Census plot of ACS Census tract was assigned an equal value. There are typically 2-3 Census blocks per Census tract. According to Iceland and Steinmetz (2003), Census tracts can however, capture the important heterogeneity that exists when comparing blocks within a tract to other blocks in different tracts. Therefore, we do not expect this assumption to significantly affect our analysis. 
The majority of FIA data were categorical, except for Carbon Stocks, Basal, and Stand age.

The units of C Stocks are tons-per-hectare $\left(\mathrm{tha}^{-1}\right)$ and were determined (Equation 1) as the sum of above-ground and below-ground tree $\mathrm{C}$ stocks for each particular Census block.

Equation (1):

$$
\text { Carbon_Stocks }_{i}=\sum_{k=1}^{n} \text { Above_Ground_Stocks }_{k}+\sum_{j=1}^{m} \text { Below_Ground_Stocks }_{j}
$$

where $i$ indexes Census blocks, and $k$ 's (j's) are live trees with diameter $>2.5 \mathrm{~cm}$ and dead trees with diameter $>7.5 \mathrm{~cm} ; n(m)$ is the total number of aboveground (belowground) live trees with diameter > $2.5 \mathrm{~cm}$ and dead trees with diameter $>7.5 \mathrm{~cm}$, for a given Census plot. The aboveground and belowground $\mathrm{C}$ were calculated for both timber and woodland species. The aboveground estimation excluded foliage, and belowground included carbon from coarse roots $>2.5 \mathrm{~cm}$ in root diameter. Carbon was assumed to be one half the value of aboveground and belowground biomass of live trees with diameter $>2.5 \mathrm{~cm}$ and dead trees with diameter $>7.5 \mathrm{~cm}$. See Woudenberg et al. (2010) for a more detailed description of $\mathrm{C}$ estimation methodologies.

Table 1. Descriptive statistics of 2010 Carbon Stocks and Ecological predictors of Carbon Stocks in Florida using USDA Forest Inventory Analysis data.

\begin{tabular}{|c|c|c|}
\hline $\begin{array}{l}\text { Factors of } \\
\text { Influence }\end{array}$ & Definition & $\begin{array}{c}\text { Mean } \\
(\text { Std Dev })\end{array}$ \\
\hline Carbon Stocks & $\begin{array}{l}\text { Total above-ground and below-ground carbon stocks in tons per } \\
\text { hectare. (Range } 0 \text { to } 333.23 \text { ) }\end{array}$ & $\begin{array}{c}49.77 \\
(50.29)\end{array}$ \\
\hline Basal & $\begin{array}{l}\text { Basal area of live trees. Cross-sectional area in square feet per acre of } \\
\text { all live trees over } 1 \text { inch at tree DBH. }\end{array}$ & $\begin{array}{c}79.20 \\
(40.38)\end{array}$ \\
\hline \multirow[t]{2}{*}{ Stand Age } & \multirow[t]{2}{*}{ Stand Age (years) } & $\begin{array}{l}37.21 \\
(27.02)\end{array}$ \\
\hline & & Percent \\
\hline \multirow{2}{*}{ Pine } & $1=$ Predominantly Pine $(n=485)$ & $1=53.77 \%$ \\
\hline & $0=$ Otherwise $(n=417)$ & $0=46.23 \%$ \\
\hline \multirow{2}{*}{ Ownership } & $1=$ Undifferentiated private $(\mathrm{n}=669)$ & $1=74.17 \%$ \\
\hline & $0=$ Otherwise $(n=233)$ & $0=25.83 \%$ \\
\hline
\end{tabular}


Site productivity class code. A classification of forestland in terms of inherent capacity to grow crops of industrial wood.

$1=0-19$ cubic feet/acre/year $(n=6)$

$2=20-49$ cubic feet/acre/year $(n=227)$

Site quality $3=50-84$ cubic feet/acre/year $(\mathrm{n}=408)$

$4=85-119$ cubic feet/acre/year $(n=197)$

$5=120-164$ cubic feet/acre/year $(n=56)$

$6=165-224$ cubic feet/acre/year $(n=7)$

$7=225+$ cubic feet/acre/year $(n=1)$

$1=$ Small diameter - Stands with at least $50 \%$ of the stocking are in small diameter trees. $(\mathrm{n}=284)$

Stand size

$2=$ Medium diameter - Stands with more than $50 \%$ of the stocking in medium and large diameter trees. $(n=262)$

3 = Large diameter - Stands with more than 50 percent of the $3=39.47 \%$ stocking is in medium and large diameter trees. $(n=356)$

\begin{tabular}{clr}
\hline \multirow{2}{*}{$\begin{array}{c}\text { Silvicultural } \\
\text { Treatment }\end{array}$} & $\begin{array}{l}1=\text { Treatment ex: site preparation, fertilizers, herbicides, etc. } \\
0=\text { Otherwise }(\mathrm{n}=865)\end{array}$ & $1=4.10 \%$ \\
& Disturbance ex: ground fire damage, drought, flooding, etc. & $1=95.90 \%$ \\
\hline \multirow{2}{*}{ Disturbance } & $1=$ Disturbance occurred between the years $2000-2010(\mathrm{n}=46)$ & \\
& $0=$ Otherwise $(\mathrm{n}=856)$ & $0=94.90 \%$
\end{tabular}

Note: DBH is Diameter at Breat Height or $1.5 \mathrm{~m}$ above the surface and " $\mathrm{n}$ " is plots, which total 902; The variable "County," which contains the county code number, was ommitted from this table due to lack of signifiance. "Std Dev" is Standard Deviation.

The predominant forest types in the study area were pine-dominated, thus a dummy variable was used to indicate the predominance of pines in a given plot. Land tenure or Ownership was also included using a dummy variable; 1 if the FIA Census plot belonged to an undifferentiated private owner (669 or $74 \%$ of plots) or 0 otherwise (e.g., State Park, National Forest or Park, etc.). Site quality, was used to characterize the inherent capacity of forestland for timber production and was coded categorically as was Stand size which was categorically coded according to three size-labels (Table 1).

Two additional dummy variables were created for Silvicultural Treatment (e.g., site preparation, fertilizers, herbicides, etc. between the years 2000-2010) and natural Disturbance (e.g. ground fire damage, drought, flooding). These variables, respectively, were 1 if the sample plot 
received any type of Silvicultural treatment (or was affected by a Disturbance, 0 otherwise). Finally, a

County categorical variable was introduced to identify the county where plot was located. The plot distribution did not cluster in any particular county (see Figure 1 to see geographic distribution of all of the plot observations). The FIA sampling grid does not consider county lines in plot allocation and Florida counties can vary widely in size and forest cover, thus county lines were not included in Figure (1).

Specific 2010 Decennial Census Data variables were used to model potential socio-ecological and economic determinants of forest carbon stocks (See the 2010 Census Summary File 1 United States [2011] for a complete description of 2010 Census data collection methodologies and procedures). We selected Ethnicity, which consisted of Hispanic, African-Americans, and White categories. Urban was also selected and is defined as all territory, population, and housing located within all urban clusters (populations of 2,500 to 50,000 or more), and used to differentiate between urban and rural populations (all territories, population, and housing located outside of Urban areas). Age, a common factor used in these studies, consisted of four categories (Table 2).

Data were supplemented by using the American Communities Survey for the year 2010 (5 year collection period) to identify six education categories. We also identified tenure or home ownership as an "Owner occupied" (a housing unit that is owner occupied or co-owner occupied, regardless of unpaid mortgage) to test the hypothesis that areas with Owner Occupied are statistically significant, and positively related to forest $\mathrm{C}$ stocks. Annual (12 months from the time of the interview) income is defined as income of the householder and all other individuals 15 years old and over in the household. These data consisted of the number of households that fell within the following five categories: under $\$ 25,000 ; \$ 25,001-\$ 49,000 ; \$ 50,000-\$ 99,000 ; \$ 100,000-\$ 199,000$ and above $\$ 200,000$.

All socioeconomic predictors were included as a percentage of the Census plot or Census tract area. For example, the income variable $\$ 50 K-\$ 99 K$ was determined by dividing the number of households in this category by the total number of households in their corresponding Census tract (or Census plot, depending on the variable). The same was done for all other socioeconomic variables. 
Table 2. Descriptive statistics of 2010 Socioeconomic Drivers of Carbon Stocks in Florida.

\begin{tabular}{|c|c|c|c|c|}
\hline Variable & Mean & Minimum & Maximum & Std. Deviation \\
\hline Hispanic & $7.46 \%$ & $0.00 \%$ & $75.20 \%$ & 10.29 \\
\hline African-Americans & $9.74 \%$ & $0.00 \%$ & $84.70 \%$ & 13.07 \\
\hline Whites & $84.15 \%$ & $0.00 \%$ & $100 \%$ & 14.99 \\
\hline No formal education & $1.15 \%$ & $0.00 \%$ & $35.00 \%$ & 2.00 \\
\hline Primary school* & $1.38 \%$ & $0.00 \%$ & $19.00 \%$ & 1.95 \\
\hline Secondary school* & $3.15 \%$ & $0.00 \%$ & $14.00 \%$ & 2.17 \\
\hline High school degree* & $37.65 \%$ & $3.00 \%$ & $100 \%$ & 8.57 \\
\hline Bachelors degree* & $17.17 \%$ & $0.00 \%$ & $60.00 \%$ & 7.92 \\
\hline Graduate degree* & $5.46 \%$ & $0.00 \%$ & $27.00 \%$ & 4.03 \\
\hline Owner occupied* & $61.76 \%$ & $0.00 \%$ & $96.00 \%$ & 13.87 \\
\hline Urban & $18.10 \%$ & $0.00 \%$ & $100 \%$ & 31.13 \\
\hline Under 21 & $25.98 \%$ & $0.00 \%$ & $57.00 \%$ & 6.79 \\
\hline $22-39$ & $29.33 \%$ & $1.00 \%$ & $79.00 \%$ & 11.10 \\
\hline $40-64$ & $36.59 \%$ & $6.00 \%$ & $58.00 \%$ & 6.12 \\
\hline 65 and greater & $16.91 \%$ & $0.00 \%$ & $76.00 \%$ & 8.51 \\
\hline Under $\$ 25 \mathrm{~K}^{*}$ & $20.70 \%$ & $0.00 \%$ & $56.00 \%$ & 8.01 \\
\hline$\$ 25 \mathrm{~K}-49 \mathrm{~K}^{*}$ & $28.87 \%$ & $0.00 \%$ & $100 \%$ & 7.30 \\
\hline$\$ 50 \mathrm{~K}-99 \mathrm{~K}^{*}$ & $31.00 \%$ & $0.00 \%$ & $58.00 \%$ & 7.02 \\
\hline \$100K-199K* & $11.05 \%$ & $0.00 \%$ & $55.00 \%$ & 7.07 \\
\hline Above $\$ 200 K^{*}$ & $1.81 \%$ & $0.00 \%$ & $45.00 \%$ & 2.82 \\
\hline
\end{tabular}

Note: $N=902$ plots for all variables. $\mathrm{K}=\$ 1000$ s. ${ }^{*}$ obtained at the Census tract level.

\subsection{Model Specification}

The 2010 carbon stocks and ecological variables from FIA observations in Florida were spatially overlaid using ARCGIS (v10) and matched with 2010 Census (blocks) and 2010 ACS (Census tracts) socio-economic information to evaluate the determinants of $\mathrm{C}$ stocks using the following Equation (2):

$$
\text { Carbon_Stocks }_{i}=\beta_{1}+\sum_{j=1}^{8} \beta_{j} \text { Socio_Ecological_Drivers }_{j i}+\sum_{k=1}^{21} \beta_{k} \text { Economic_Drivers }_{k i}+\varepsilon_{i}
$$

where Carbon_Stocks is constructed based on Equation 1), $i$ indexes Census blocks, $j$ indexes the 8 Socio-ecological drivers summarized in Table 1, and $k$ indexes the 21 Economic Drivers summarized 
in Table 2. The omitted variables are: Whites, High School, Under 21-years of age, Income Under $\$ 25 K$ (thousand) per-year.

We used Multiple Regression Analysis (MLR) to obtain estimates based on the specification in Equation 2. One limitation of MLR is that it limits the spectrum of analysis by only examining the effects of explanatory variables at the conditional mean of the dependent variable. To overcome this, we employ the Quantile Regression (QR) technique by Koenker and Basset (1978). With QR, we are able to better explore the distributional effects of socio-ecological and economic determinants at various points of the conditional $\mathrm{C}$ stock distribution. Additionally, the $\mathrm{QR}$ estimates are unaffected by the presence of outlying observations, whereas MLR can be severely distorted by such factors (Green, 2003). QR has also been used in studies that control control for socioeconomic factors (e.g. Marques and Fuinhas, 2011). In our distributional analysis we examine a total of 19 quantiles, starting from the $5^{\text {th }}$ percentile, and increasing by 5 percentiles until the $95^{\text {th }}$ percentile of the C-stock distribution. QR is performed by minimizing the following equation from Koenker and Bassett (1978):

$$
\underset{\beta \in \mathfrak{R}^{k}}{\operatorname{Min}} \sum_{i \in\left\{i: y_{i} \geq x_{i} \beta\right\}} \theta\left|y_{i}-x_{i} \beta\right|+\sum_{i \in\left\{i: y_{i}<x_{i} \beta\right\}}(1-\theta)\left|y_{i}-x_{i} \beta\right|
$$

where $\theta$ is the $\theta^{\text {th }}$ quantile (between 0 and 1), $y_{i}$ is the dependent variable ( $i$ indexes individual FIA plot observations), $x_{i}$ is a $(j+k)$ by 1 vector of factors of influence, and $\beta$ the vector of correspondent coefficients.

\subsection{Multiple Regression Analysis of Socio-Ecological and Economic Predictors of Carbon Stocks}

Based on the Shapiro-Wilks and a quantile-quantile plot analysis we failed to reject the null hypothesis of normality. Although we failed to reject the null hypothesis of homoskesticity (BreushPagan test p-value < 0.00), we used robust standard errors in our inferential analysis (White, 1980). Multicollinearity in the MLR model was examined using the variance inflation factor (VIF) of each of the regression coefficients (Greene, 2003; pg. 57), and we note that the VIF for each variable was below the conventional tolerance threshold (all were below VIF =4). Outliers were analyzed using the 
Cook's Distance (D) post-estimation command but no issues were found. Finally, we removed 30

observations with clear measurement error, namely, very high levels of Basal, zero forest C stocks, and zero Stand age. All of our statistical analyses were done using STATA (14.0) statistical software.

\section{Results}

\subsection{Socio-Ecological and Economic Predictors of Carbon Stocks}

Results indicate that half of the ecological variables were significant drivers of forest $\mathrm{C}$ stocks $(\mathrm{p}<0.05$; Table 3$)$. Eight of the socioeconomic variables were also significant $(\mathrm{p}<0.10$; Table 3$)$. Overall, the model performed well, was highly statistically significant (F-statistic $\mathrm{p}<0.00$ ), and provided good predictive power $\left(\mathrm{R}^{2}=0.59\right)$.

Table 3. Multiple Linear Regression Estimates of Socio-Ecological and Economic Factors Influencing Florida Carbon Stocks based on 2009 - 2011 Forest Inventory Plot observations.

\begin{tabular}{|c|c|c|c|c|}
\hline \multirow[b]{2}{*}{ Factors of Influence } & \multicolumn{3}{|c|}{ Robust } & \multirow[b]{2}{*}{ Prob $>|t|$} \\
\hline & Estimate & Std Error & t Ratio & \\
\hline Basal* & 0.46 & 0.03 & 15.05 & $0.00 *$ \\
\hline Pine forests ${ }^{0,1}$ & -0.48 & 2.23 & -0.21 & 0.83 \\
\hline Ownership ${ }^{0,1}$ & 1.27 & 2.87 & 0.44 & 0.66 \\
\hline Site quality* & 4.35 & 1.41 & 3.07 & $0.00 *$ \\
\hline Stand size* & 4.65 & 1.49 & 3.13 & $0.00 *$ \\
\hline Silvicultural $^{0,1}$ & 0.88 & 3.53 & 0.25 & 0.80 \\
\hline Disturbance $^{0,1}$ & 2.83 & 4.81 & 0.59 & 0.56 \\
\hline Stand age* & 0.47 & 0.06 & 7.83 & $<0.00 *$ \\
\hline Hispanic* & -0.50 & 0.16 & -3.18 & $0.00 *$ \\
\hline African-Americans** & -0.16 & 0.09 & -1.73 & $0.08 * *$ \\
\hline Whites & Omitted & & & \\
\hline No formal education & -0.61 & 0.57 & -1.08 & 0.28 \\
\hline Primary school & 0.59 & 0.83 & 0.72 & 0.47 \\
\hline Secondary school & -0.10 & 0.55 & -0.18 & 0.86 \\
\hline High School & Omitted & & & \\
\hline Bachelors degree & 0.30 & 0.26 & 1.16 & 0.25 \\
\hline Graduate degree* & 1.02 & 0.51 & 1.98 & $0.05^{*}$ \\
\hline
\end{tabular}




\begin{tabular}{|c|c|c|c|c|}
\hline \multirow[b]{2}{*}{ Factors of Influence } & \multicolumn{3}{|c|}{ Robust } & \multirow[b]{2}{*}{ Prob $>\mid \mathbf{t}$} \\
\hline & Estimate & Std Error & t Ratio & \\
\hline Owner occupied & 0.14 & 0.10 & 1.41 & 0.16 \\
\hline Urban & 0.06 & 0.04 & 1.27 & 0.20 \\
\hline Under 21 & Omitted & & & \\
\hline $22-39 *$ & 0.35 & 0.16 & 2.14 & $0.03 *$ \\
\hline $40-64$ & 0.15 & 0.20 & 0.77 & 0.44 \\
\hline 65 and greater* & -0.45 & 0.19 & -2.37 & $0.02 *$ \\
\hline Under $\$ 25 \mathrm{~K}$ & Omitted & & & \\
\hline$\$ 25 \mathrm{~K}-49 \mathrm{~K}$ & 0.01 & 0.20 & 0.03 & 0.98 \\
\hline$\$ 50 \mathrm{~K}-99 \mathrm{~K}^{*}$ & -0.69 & 0.23 & -3.08 & $0.00 *$ \\
\hline$\$ 100 \mathrm{~K}-199 \mathrm{~K}^{* *}$ & -0.50 & 0.29 & -1.70 & $0.09 * *$ \\
\hline Above $\$ 200 \mathrm{~K}^{* *}$ & -0.91 & 0.55 & -1.67 & $0.09 * *$ \\
\hline County* & -0.09 & 0.03 & -2.86 & $0.00 *$ \\
\hline Intercept & -16.59 & 17.98 & -0.92 & 0.36 \\
\hline $\begin{array}{l}\text { Prob > F } \\
\text { Number of Observations }\end{array}$ & $\begin{array}{l}<0.00 \\
902\end{array}$ & & & \\
\hline R-Square Statistic & 0.59 & & & \\
\hline
\end{tabular}

Note: Pine: ${ }^{0}$ Predominantly Pine and ${ }^{1}$ Otherwise; Silvicultural treatment: ${ }^{0}$ untreated and treated; Ownership: ${ }^{0}$ public and ${ }^{1}$ private; Disturbance: ${ }^{0}$ undisturbed, ${ }^{1}$ disturbed; Site quality $=1,2,3,4,5,6$ and 7 (See Table 1 for descriptions); $*$ Effect of factor of influence is statistically significant at value of $\alpha=0.05$; ** Effect of factor of influence is statistically significant at value of $\alpha=0.10$; Prob $>\mathrm{F}$ is the $\mathrm{p}$-value associated with the F-statistic.

All the significant ecological drivers in the MLR model exhibited the theoretically expected signs associated with forest C stocks (Timilsina et al., 2013; Cademus et al. 2014; Szantoi et al., 2012). On average, a one-year increase in Stand-age is associated with an increase of 0.47 tons of C storage per hectare. An additional square foot per acre of Basal area is also related to an increase of 0.46 tons of C storage per hectare. Disturbance and Silvicultural treatments were not significant and may be attributed to the small amount of occurrences in our data: only $5.07 \%$ of the observations recorded a Disturbance, and $4.07 \%$ received a Silvicultural Treatment. Undifferentiated private Ownership of forests and the Pine indicator were also found to lack significance $(\mathrm{p}>0.10)$.

Socioeconomic predictors in our model are reported as a percentage of each category, within their respective Census plot or Census tract, where for observation $i$, the sum of all variables in each category (including the omitted category) equals $100 \%$. Results indicate that Census areas in our 
sample with predominantly minority residents, of population age 65 and greater, and annual household

incomes greater $\$ 50$ thousand, are negatively associated (with respect to the base or omitted category) with forest C stocks. Similarly, positive signs of variables age of 22-39 years and Graduate degrees indicate that areas in our data with a higher percentage of Graduate degrees, and population age of 2239 years are positively associated with higher forest C stocks in Florida. Owner occupied and Urban were not significant $(\mathrm{p}>0.10)$.

\subsection{Distributional Effects of Socio-Ecological and Economic Factors on Carbon stocks}

We summarize our estimated results based on QR analysis in Figure 2. All the determinants from Equation 2, with the exception of Disturbance, Secondary school, and age 40-64 years, had a statistically significant $(\mathrm{p}<0.05)$ effect in at least one of the 19 quantiles of the $\mathrm{C}$ stock distribution we considered in this study. Figure 2, however, only shows results for an important subset of all the determinants included in our analysis (results not reported here are available upon request). Each graph depicts the estimated effect, represented by a point, at a particular percentile and its respective confidence interval (CI), denoted by the long dash at the end of the vertical dashed line. In general, the QR analysis is suggestive of the heterogeneity in the effect of certain determinants on the conditional C stock distribution. For example, interesting trends are noted for the ecological determinants of Basal area, Stand age, Stand size, and Site quality, in Figure 2 (a), (b), (c), and (d), respectively, where they all have a positive effect that increases as we analyze larger percentiles of the $\mathrm{C}$ stock distribution. Basal area and Stand age effects are statistically significant throughout the C stock distribution, while effects of Stand size and Site quality are only significant from the $25^{\text {th }}$ to $90^{\text {th }}$ percentile. We deem important to highlight the rate at which the effect of Basal area increases with the distribution of $\mathrm{C}$ stocks, relative to the distributional effects of the other determinants.

As shown in Figure 2 (e), the effect of Ownership on the distribution of C stocks is negative below the $55^{\text {th }}$ percentile, however, statistically significant only in percentiles $30^{\text {th }}$, while the effect is positive beyond the $60^{\text {th }}$ percentile albeit insignificant. Importantly, using a 90 percent confidence interval most of the effects at lower percentiles are significant. Being in an Urban population is 
positively related to $\mathrm{C}$ stock at all but one of the studied percentiles $\left(95^{\text {th }}\right)$, where only the effect at the

$5^{\text {th }}$ percentile is statistically significant (most of the effects below the median are significant at a 90 percent level of confidence) as shown in Figure 2 (f).

Figure $2(\mathrm{~g})$ features the effects of a one percent increase in Hispanic residents as compared to White (baseline). The effect of this variable is negative and significant for all quantiles, except the $10^{\text {th }}$ and $95^{\text {th }}$ percentiles. Relative to white, African-American is also negatively related to $\mathrm{C}$ stocks at all points in its distribution, however, the effect is only significant at a 90 percent level of confidence for the $70^{\text {th }}$ and $90^{\text {th }}$ percentiles. Relative to the age category of Under 21 , there is not a high degree of heterogeneity in the effect of increasing the proportions of age groups 22-39 years of age and 65 years and greater on the studied quantiles of C stock. Appendix A (c) shows the effect of a one percent increase in population age 65 years and greater, as compared to the omitted category Under 21.

Relative to High school, having a Graduate degree positively impact C stock percentiles higher than $30^{\text {th }}$, however, this effect is only significant at the $90^{\text {th }}$ percentile as shown in Figure $2(\mathrm{~h})$. This trend is consistent with other education categories larger than High school. On the other hand, No formal education has a negative impact for most (above and below the $50^{\text {th }}$ and $70^{\text {th }}$ percentiles) of the C stock distribution. Relative to the income category of Under $\$ 25 K$, increasing the proportion of higher income categories has, in general, a negative effect throughout the $\mathrm{C}$ stock distribution. The latter can be seen in Figure 2 (i) for income category $\$ 50 K-99 K$ and in the Appendix A (b) for Above $\$ 200 K$.

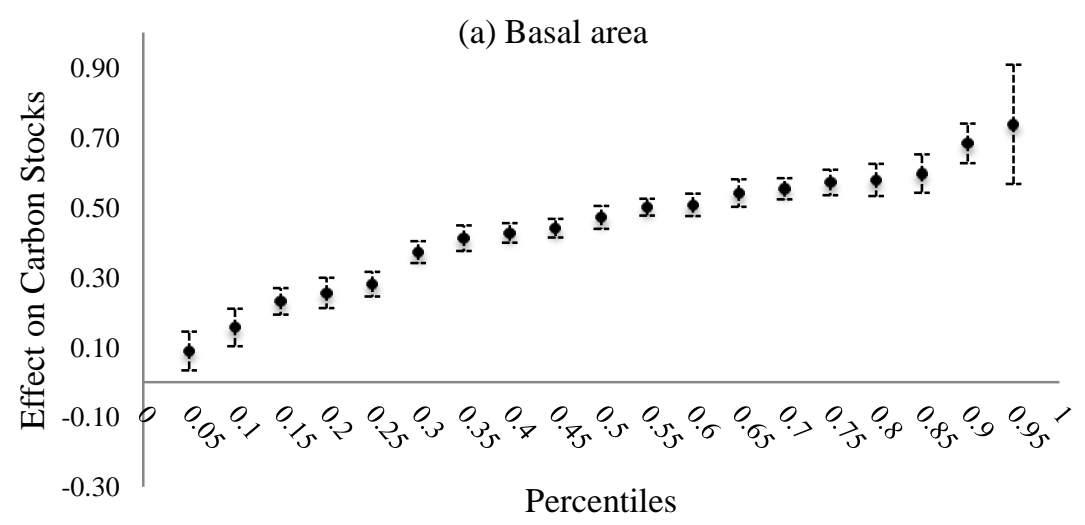



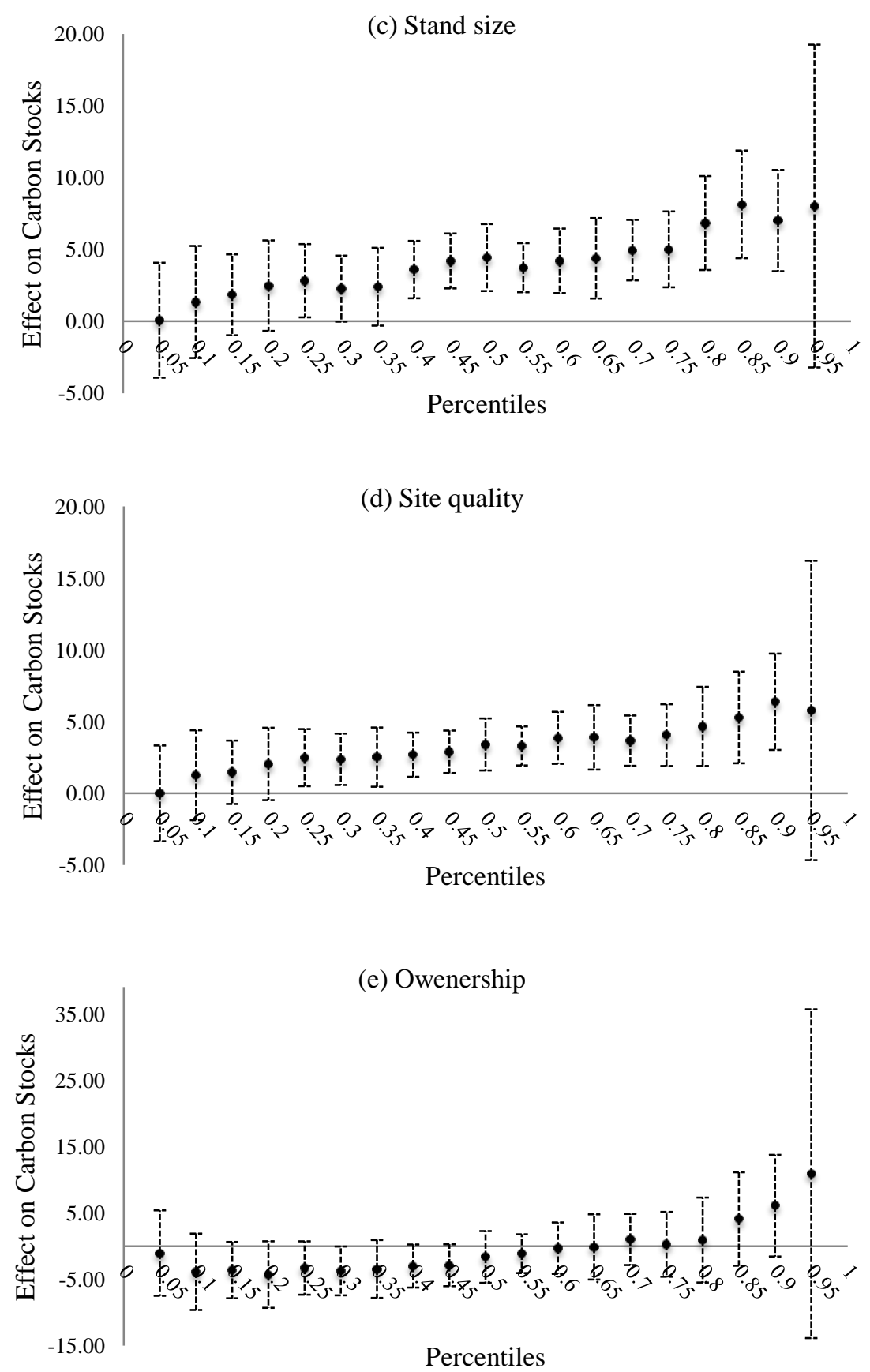


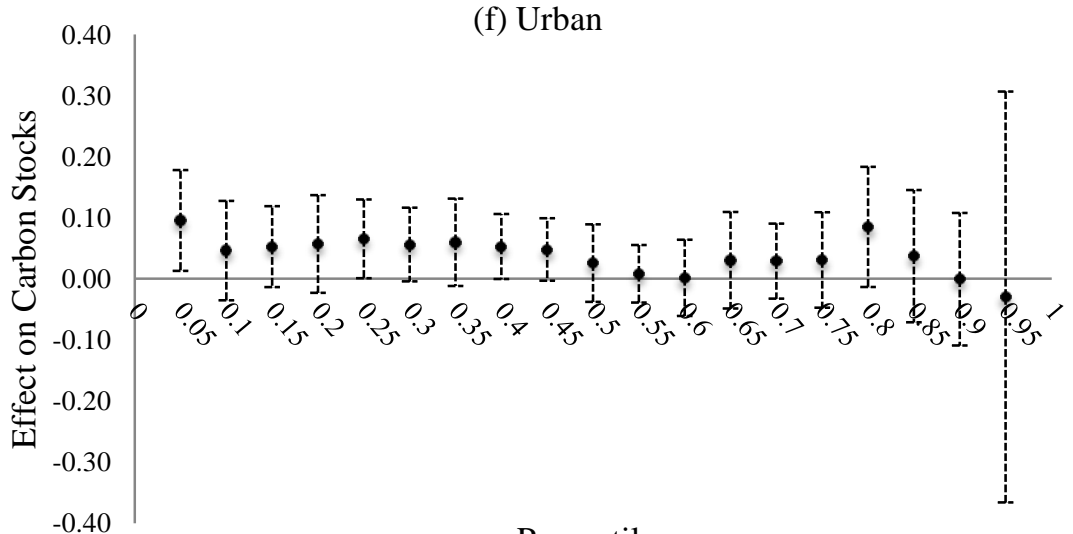

Percentiles

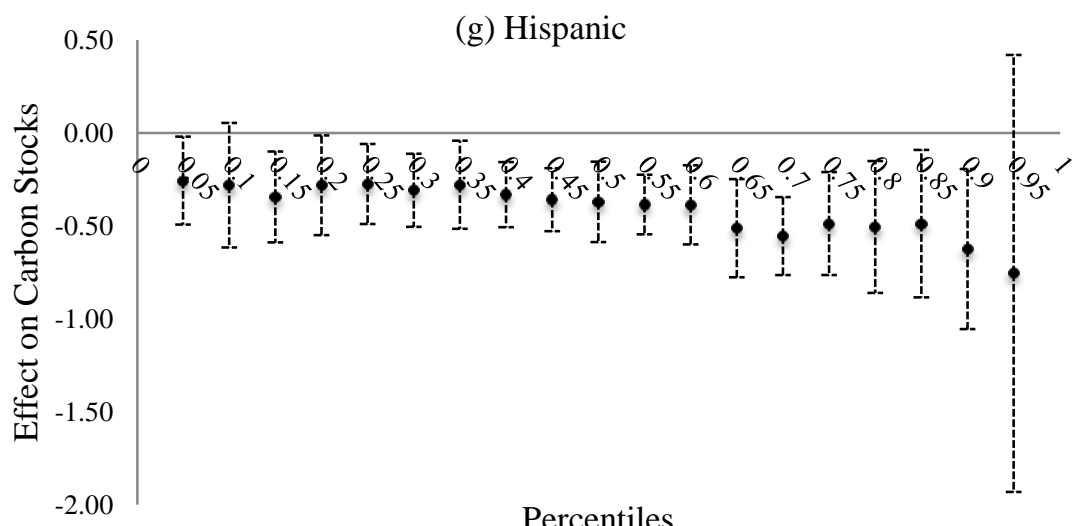

Percentiles
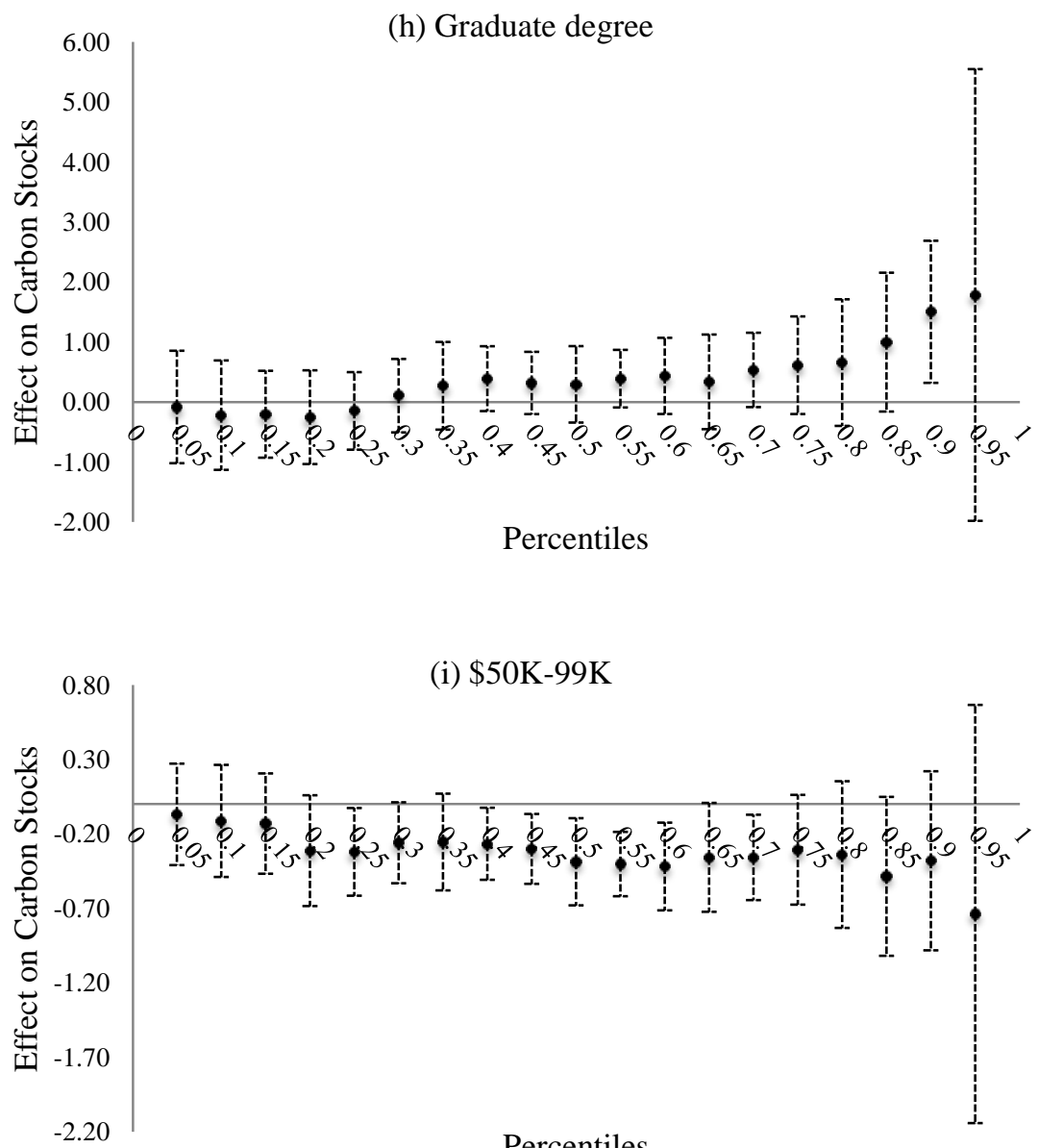

Percentiles 
Figure 2. Quantile Regression Estimates of Socio-ecological and Economic Determinants of Florida Carbon Stocks. Note: 95\% Confidence Intervals denoted by a long dash at end of the dashed vertical lines.

\section{Discussion}

Our analysis of socio-ecological and economic drivers of C stocks found several statistically significant relationships. Our empirical strategy highlights the importance of complementing the analysis based on mean estimates with an assessment of the distributional effects of the $\mathrm{C}$ stock determinants. Our findings on basal area, site quality, stand size, and stand age as significant ecological predictors of forest carbon stocks are consistent with other studies from this region (Timilsina et al., 2013; Cademus et al., 2014; Szantoi et al., 2012). Finding that Site quality positively affects C stocks is similar to what was found by Timilsina et al. (2013) for forest C hotspots in Florida, and by Cademus et al. (2014) for forest C sequestration in North Florida. Likewise, our QR analysis results are consistent with Timilsina et al. (2013) with respect to the influence of various forest types (in this case Pine) on $\mathrm{C}$ sequestration, and with both of those studies regarding the lack of influence of Disturbance. However, our results differ with Cademus et al. (2014) on the influence of Stand age, which we found to be positively associated with $\mathrm{C}$ sequestration. We also found Silvicultural treatments to be significant positive drivers of C stocks - similar to Cademus et al. (2014), but only our QR analysis found the variable to be statistically significant at some points of the C stock distribution. It is important to highlight this last finding, because it shows that mean effects mask effects at other points of the conditional distribution, which might have policy implications. Please note that differences between this and Cademus et al. (2014) may be due to the fact that we studied C stocks and they modeled $\mathrm{C}$ sequestration.

Similar to Joshi and Arano (2009) and Szantoi et al. (2012), we found that more education was associated with an increase in forest $\mathrm{C}$ stocks, but we note that these effects are concentrated in the upper portion of the $\mathrm{C}$ stock distribution-their analysis was limited to linear regression. In contrast to Joshi and Arano (2009) and Szantoi et al. (2012), our results show a positive relationship between 
forest $\mathrm{C}$ stocks and younger populations (age 22-39 years) and a negative association with higher

levels of income. Similar to Szantoi et al. (2012), our QR results found Owner occupied to be a positive influence on C stocks. Differences with Joshi and Arano's (2009) findings may be due to inherent differences in dependent variables (we modeled forest $\mathrm{C}$ stocks and they focused on forest management decisions), or from regional variations of socio-economic drivers. Our results for rural natural forests (i.e., FIA plots) also were similar to the socio-economic factors driving urban forest cover in Florida as identified by Szantoi et al. (2012; Figure 2i). Finally, our results agree with Fischer and Charnley (2010) and Beach et al.'s (2005) on education, silvicultural treatments, and landowner age; but we find different results for higher categories of income with our QR approach.

The results from both the QR and MLR models show broad agreement, but there are important differences in the number of significant factors of influence across the models. All but three variables of our observed variables were significant in at least one of the 19 quantiles observed by QR, but only about half (13 of 25) were significant in MLR. Although the signs were consistent between the significant variables of QR and MLR, there is clear evidence of heterogeneity in the effects of these important determinants of C stocks, which are not captured by the MLR analysis.

Studies in our literature review that analyze determinants of forest $\mathrm{C}$ stocks focus on mean effects - a result of analyses based on least square regression. Our QR results suggest that this might be a shortcoming given the differing impacts of several variables along the low-to-high $\mathrm{C}$ storage spectrum. For example, Stand size, whose effect is positive and statistically significant in the upper half of the distribution, but indistinguishable from zero in the bottom half. Recently, considerations of heterogeneity have provided important insights into the dynamic drivers of deforestation across time and space (e.g. Damatte and Delocate, 2012). Our exploration of the heterogeneous effects of several variables on the distribution of $\mathrm{C}$ stocks using $\mathrm{QR}$ analysis adds to this literature.

Previous research has indicated that forest $\mathrm{C}$ sequestration is boon for both forest landowners (given the added income) and society (given the relative marginal costs of $\mathrm{C}$ emissions reduction; Escobedo et al., 2010; Qureshi et al., 2011). Baker et al.'s (2010) simulation of a national C cap-and- 
trade program on the agricultural and forestry sectors from 2000 to 2080 found large benefits to both

sectors with net gains of up to $\$ 3.6$ billion per year for forestry, and 180 to $300 \mathrm{TgCO}_{2}$ annualized emissions from forests at just $\$ 15$ per $\mathrm{tCO}_{2} \mathrm{e}$. This amount of $\mathrm{C}$ sequestration equates to nearly $15 \%$ of the emissions reduction goal agreed by the Obama administration and Chinese counterparts in November 2014 (Landler, 2014), and can be achieved less expensively than other popular policy alternatives, like demand-side efficiency programs ( $\$ 16$ to $\$ 24$ per $\mathrm{tCO}_{2} \mathrm{e}$ ) and developing renewable energy capacity ( $\$ 10$ to $\$ 40$ per $\mathrm{tCO}_{2} \mathrm{e}$; EPA Pollution Emission Guidelines, 2014).

It is important to note that Florida, as opposed to water quality and wildlife habitat protection, does not have policies in place - per se- that explicitly encourage forest carbon sequestration and as such policies would need to be created. However, very recent national and local-level policies are relevant in Florida such as the US Environmental Protection Agency's Clean Power Plant rule mentioned above. Additionally, recent federal policies apply to Florida such as Memorandum M-1601 that directs federal agencies to integrate ecosystem-services (i.e. carbon offsets) as part of "programs and projects to help maintain ecosystem and community resilience" (https://www.whitehouse.gov/sites/default/files/omb/memoranda/2016/m-16-01.pdf ). At the Statelevel Florida has explicitly required consideration of environmental justice in several policy contexts (air pollution, brownfields redevelopment, land use permitting and siting, and public health; Bonorris 2010) and in assessment of factors like "equity, human dignity, fairness, and distributive impacts" (Executive Order 13563, 2011), suggesting that this is an important policy goal for the state. Also local Florida governments are promoting the use of urban forest management activities (e.g. tree plantings, conservation programs) to offset anthropogenic carbon emissions from cities (Escobedo et al., 2010). We therefore propose that our findings could be used for developing and promoting such state-level forest $\mathrm{C}$ offset policies and their uptake.

\section{Conclusion}

While other studies have assessed drivers of forest C stocks, no other statewide studies have taken a socio-ecological and economic approach or employs models that allow direct consideration of 
distributional effects, like QR. Our study also analyzed two factors not previously accounted for in

similar studies the Florida context: Pine forest types and Basal area. Our approach suggests that by explicitly considering distributional impacts, local, state, and federal policy makers can develop C sequestration strategies that target "low hanging fruit" (areas with high $\mathrm{C}$ stock percentiles), while considering the broader social implications of compliance strategies that include forest $\mathrm{C}$ offsets (e.g. environmental justice and other ecosystem service co-benefits).

In heavily forested states like Florida, forests are expected to play a crucial role in meeting EPA emissions reduction targets (e.g., Stainback and Alavalapati, 2002; Mulkey et al., 2008; Dwivedi et al., 2009). Indeed, such an approach, which has been shown to be more economically effective than other $\mathrm{C}$ emissions reduction alternatives, clearly satisfies economic criteria for policy assessments. However, little is known about its distributional impacts. The EPA CPP rule will likely force Florida policy makers to consider trade-offs between various policy instruments (e.g., emissions reductions from coal power plants, capturing $\mathrm{C}$ emissions using natural or urban forest projects, etc.) and management objectives (ecosystem services and goods or land acquisition for urbanization or conservation). Thus models, including those presented here that identify the socio-ecological and economic characteristics of an area that will be managed for $\mathrm{C}$ storage, are of interest to policy makers seeking to develop a portfolio for emissions compliance to meet their EPA imposed deadlines. Predictive model results can be used as needed to more effectively prevent forest degradation, improve forest management activities, increase forested areas in urban or natural settings, and incentivize landowners to participate in $\mathrm{C}$ offset and other ecosystem service programs. A comprehensive approach - one that contemplates not just economic and environmental, but also social criteria - has the potential to converge on several socially and ecologically important goals.

\section{Acknowledgements}

We thank the Pine Integrated Network: Education, Mitigation, and Adaptation project (PINEMAP); a Coordinated Agricultural Project funded by the USDA National Institute of Food and 
Agriculture, Award \#2011-68002-30185 for financial support and the USDA Forest Service

\begin{abstract}
FIA program for providing data. We also thank Sonia Delphin for valuable contributions to this work.
\end{abstract}

\title{
References
}

Adams, D.M., Alig, R.J., McCarl, B.A., Callaway, J.M., Winnett, S.M., 1999. Minimum cost strategies for sequestering carbon in forests. Land Econ. 75 (3), 360-374.

American Community Survey - 2010 Subject Definitions. Retrieved 12/4/15, from http://www.census.gov/acs/www/Downloads/data_documentation/SubjectDefinitions/2010_ACSS ubjectDefinitions.pdf

American Community Survey, 5-Year Estimates. Retrieved 2/10/15, from http://www.census.gov/quickfacts/table/INC110213/00,12

Baker, S.B., McCarl, B.A., Murray, B.C., Rose, S.K., Align, R.J., Adams, D., Latta, G., Beach, R., Daiqneault, A., 2010. Net Farm Income and Land Use under a U.S. Greenhouse Gas Cap and Trade. Policy Issues. P17 (April), 1-5.

Beach, R.H., Pattanayak, S.K., Yang, J.C., Murray, B.C., Abt, R.C., 2005. Econometric studies of nonindustrial private forest management: a review and synthesis. Forest Policy and Economics. 7(3), 261-281.

Bennett, E.M., Peterson, G.D., Gordon, L.J., 2009. Understanding relationships among multiple ecosystem services. Ecol. Lett. 12, 1394-1404.

Bonorris, S. 2010. Environmental Justice for All: A Fifty State Survey of Legislation, Policies, and Cases $\left(4^{\text {th }}\right.$ ed.). http://gov.uchastings.edu/public-law/docs/ejreport-fourthedition.pdf

Brown, K., Corbera, E., 2003. Exploring equity and sustainable development in the new carbon economy. Climate Policy. 3(sup1), S41-S56. 
Brown, M. J., Nowak, J., 2012. Florida, 2010 forest inventory and analysis factsheet. U.S. Department of Agriculture Forest Service. 1-5.

Butler, B.J., Leatherberry, E.C., 2004. America's family forest owners. Journal of Forestry. 102, 7, 414.

Bureau of Economic and Business Research. Retrieved 2/10/15, from http://www.bebr.ufl.edu/data/series/catalog/alphabetical/all

Cademus R., Escobedo F.J., McLaughlin D., Abd-Dlrahman A., 2014. Analyzing trade-offs, synergies, and drivers among timber production, carbon sequestration, and water yield in Pinus elliottii forests in southeastern USA. Forests. 5, 1409-1431.

Caplow, S., Jagger, P., Lawlor, K., Sills, E., 2011. Evaluating land use and livelihood impacts of early forest carbon projects: Lessons for learning about REDD+. Environmental Science \& Policy. $14(2), 152-167$.

2010 Census of Population. Retrieved 2/10/15, from http://www.census.gov/quickfacts/table/INC110213/00,12

2010 Census Summary File 1 United States. Prepared by the U.S. Census Bureau, 2011. Retrieved 11/9/14, from http://www.census.gov/prod/cen2010/doc/sf1.pdf

Census Population and Housing Unit Estimates. Retrieved 2/10/15, from http://www.census.gov/popest/

Charnley, S., Diaz, D., Gosnell, H., 2010. Mitigating climate change through small-scale forestry in the USA: opportunities and challenges. Small-scale Forestry. 9(4), 445-462.

County Business Patterns. 2014. U.S. Bureau of the Census. Retrieved 2/10/15, from http://www.census.gov/econ/cbp/

Damette, O., Delacote, P., 2012. On the economic factors of deforestation: What can we learn from quantile analysis? Economic Modelling. 29(6), 2427-2434. 
De Groot, R.S., Wilson, M.A., Boumans, R.M.J., 2002. A typology for the classification, description

and valuation of ecosystem functions, goods and services. Ecol. Econ. 41, 393-408.

Delphin, S., Escobedo, F.J., Abd-Elrahman, A., Cropper, W., Jr., 2013. Mapping potential carbon and timber losses from hurricanes using a decision tree and ecosystem services driver model.

J. Environ. Manag. 129, 599-607.

Dwivedi, P., Alavalapati, J.R.R., Susaeta, A., Stainback, A., 2009. Impact of carbon value on the profitability of slash pine plantations in the southern United States: An integrated life cycle and Faustmann analysis. Can. J. For. Res. 39, 990-1000.

EPA, 2014. Inventory of U.S. Greenhouse Gas Emissions and Sinks: 1990-2012. USEPA \#430-R-14003. U.S. Environmental Protection Agency. Office of Atmospheric Programs.

EPA, 2015. Carbon Pollution Emission Guidelines for Existing Stationary Sources: Electric Utility Generating Units; Final Rule. Federal Register Vol. 80 No. 205, October 23. Retrieved 1/15/2016 from: https://www.gpo.gov/fdsys/pkg/FR-2015-10-23/pdf/2015-22842.pdf

EPA Guidelines, 2014. Retrieved 8/15/2014 from: https://www.federalregister.gov/articles/2014/06/18/2014-13726/carbon-pollution-emissionguidelines-for-existing-stationary-sources-electric-utility-generating\#footnote-108

EPA Pollution Emission Guidelines, 2014. Carbon Pollution Emission Guidelines for Existing Stationary Sources: Electric Utility Generating Units" (79 FR 34829). Retrieved 12/1/2014 from: http://www.regulations.gov/\#!documentDetail;D=EPA-HQ-OAR-2013-0602-0001

EPA Press Office, 2014. Retrieved 8/12/2014 from: http://yosemite.epa.gov/opa/admpress.nsf/d0cf6618525a9efb85257359003fb69d/5bb6d20668b9a1 8485257ceb00490c98!OpenDocument

Escobedo, F., Varela, S., Zhao, M., Wagner, J. E., \& Zipperer, W. 2010. Analyzing the efficacy of subtropical urban forests in offsetting carbon emissions from cities. Env. Sci. Pol. 13(5), 362-372. 
Fischer, A. P., Charnley, S., 2011. Social and cultural influences on management for carbon sequestration on US family forestlands: a literature synthesis. International Journal of Forestry Research. 2010.

Florida Geographic Data Library (FGDL). Available online: http://www.fgdl.org (accessed on 17 February 2012).

Florida Inventory Analysis National Program. Available online: http://www.fia.fs.fed.us (accessed on 18 March 2012).

Greene, W.H., 2003. Econometric Analysis. 5th ed. Upper Saddle River, NJ: Prentice Hall.

Iceland, J. and Steinmetz, E., 2003. The effects of using census block groups instead of census tracts when examining residential housing patterns. Bureau of the Census.

Jindal, R., Swallow, B., Kerr, J., 2008. Forestry-based carbon sequestration projects in Africa: Potential benefits and challenges. Natural Resources Forum. 32 (2), 116-130. Blackwell Publishing Ltd.

Joshi, S., Arano, K.G., 2009. Determinants of private forest management decisions: a study on West Virginia NIPF landowners. For. Pol. Econ. 11(2), 118-125.

Kaetzel, B.R., Majumdar, I., Teeter, L.D., Butler B.J., 2012. Regional Differences among Family Forest Landowners Using National Woodland Owner Survey Results. South. J. Appl. For. 36(3), $141-145$.

Koenker, R., Bassett Jr., G., 1978. Regression quantiles. Econometrica: Journal of the Econometric Society. 46(1), 33-50.

Landler, M., 2014. U.S. and China Reach Climate Accord After Months of Talks. The New York Times. November 11. Print. 
Lubowski, R., Plantinga, A., Stavins, R., 2006. Land-use change and carbon sinks: econometric estimation of the carbon sequestration supply function. Journal of Environmental Economics and Management. 51, 135-152.

Markowski-Lindsay, M., Stevens, T., Kittredge, D.B., Butler, B.J., Catanzaro, P., Dickinson, B.J., 2011. Barriers to Massachusetts forest landowner participation in carbon markets. Ecol. Econ. 71, 180-190.

Marques, A. C., Fuinhas, J. A., 2011. Do energy efficiency measures promote the use of renewable sources? Environmental Science \& Policy, 14(4), 471-481.

Miller, K.A., Snyder, S.A., Kilgore, M.A., 2012. An assessment of forest landowner interest in selling forest carbon credits in the Lake States, USA. Forest Policy and Economic. 25, 113-122.

Mulkey S., Alavalapati, J., Hodges, A. Wilkie, A.C., Grunwald, S., 2008. Opportunities for greenhouse gas reduction by agriculture and forestry in Florida. University of Florida, School of Natural Resources and Environment - Department of Environmental Defense, Washington D.C.

Ney, R.A., Schnoor, J.L., Mancuso, M.A., 2002. A methodology to estimate carbon storage and flux in forestland using existing forest and soils databases. Environmental Monitoring and Assessment. 78, 291-307.

Parks, P., Hardie, I., 1995. Least-cost forest carbon reserves: cost-effective subsidies to convert marginal agricultural land to forests. Land Economics. 71(1), 122-136.

Qureshi, A., Badola, R., Hussain, S. A., 2012. A review of protocols used for assessment of carbon stock in forested landscapes. Environmental Science \& Policy. 16, 81-89.

Richards, K.R., Stokes, C., 2004. A review of forest carbon sequestration cost studies: a dozen years of research. Climatic Change. 63(1-2), 1-48.

Smith, S.K., Rayer, S., Cody, S., 2011. Florida Population: Census Summary 2010. Bureau of Economic and Business Research, University of Florida. 
Smith, W. B., Miles, P. D., Perry, C. H., Pugh, S. A., 2009. Forest Resources of the United States, 2007. General Technical Report WO-78, U.S. Department of Agriculture Forest Service, Washington Office.

Schwenk, W.S., Donovan, T.M., Keeton, W.S., Nunery, J.S., 2012. Carbon storage, timber production, and biodiversity: Comparing ecosystem services with multi-criteria decision analysis. Ecol. Appl. $22,1612-1627$.

Stainback, G.A. \& Alavalapati, J.R.R. (2002). Economic analysis of slash pine forest carbon sequestration in the southern US. Journal of Forest Economics, 8, 105-117.

Stavins, R.N., 1999. The costs of carbon sequestration: a revealed-preference approach. Am. Econ. Rev. 89(4), 994-1009.

Stein, T., Kil, N., Frank, A., Adams, A.E., Adams, D.C., Escobedo, F.J., 2013. Public land management agencies' and nonindustrial private forest landowners' perceptions about ecosystem services, University of Florida-IFAS. Available online: https://edis.ifas.ufl.edu/fr380 (accessed on 11 June 2014).

Szantoi, Z., Escobedo, F., Wagner, J., Rodriguez, J.M., Smith, S., 2012. Socio-economic Factors and Urban Tree Cover Policies in a Subtropical Urban Forest. GIScience and Remote Sensing. 49, 428449.

Timilsina, N., Escobedo, F.J., Cropper, W.P., Jr., Abd-Elrahman, A., Brandeis, T.J., Delphin, S., 2013. Lambert, S. A framework for identifying carbon hotspots and forest management drivers. J. Environ. Manag. 114, 293-302.

White Jr., H.L., 1980. A heteroskedasticity-consistent covariance matrix estimator and a direct test for heteroskedasticity. Econometrica. 48, 817-838.

Woodbury P.B., Smith J.E., Heath L.S., 2007. Carbon sequestration in the U.S. forest sector from 1990 to 2010. Forest Ecology and Management. 241, 14-27. 
Woudenberg, S.W., Conkling, B.L., O’Connell, B.M., LaPoint, E.B., Turner, J.A., Waddel, K.L.,

2010. The Forest Inventory and Analysis Database: Database Description and User's Manual

Version 4.0 for Phase 2; General Technical Report RMRS-GTR-245; US Department of

Agriculture Forest Service, Rocky Mountain Research Station: Fort Collins, CO, USA.

Appendix A. 95 Percent Confidence Intervals for Quantile Regression Estimates of Socio-Ecological and Economic Determinants of Florida Carbon Stocks. Note: 95\% Confidence Intervals are denoted by a long dash at the end of the dashed vertical lines.

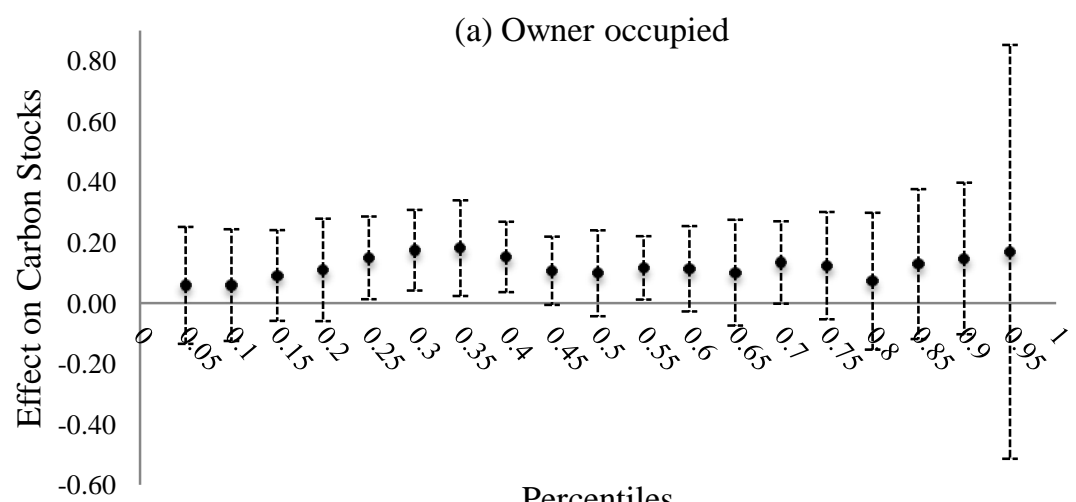

Percentiles

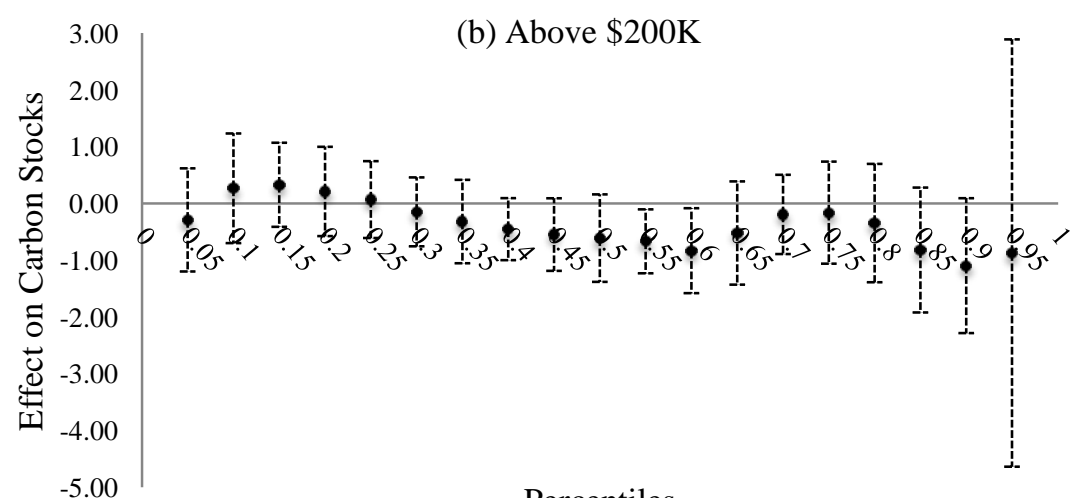

Percentiles

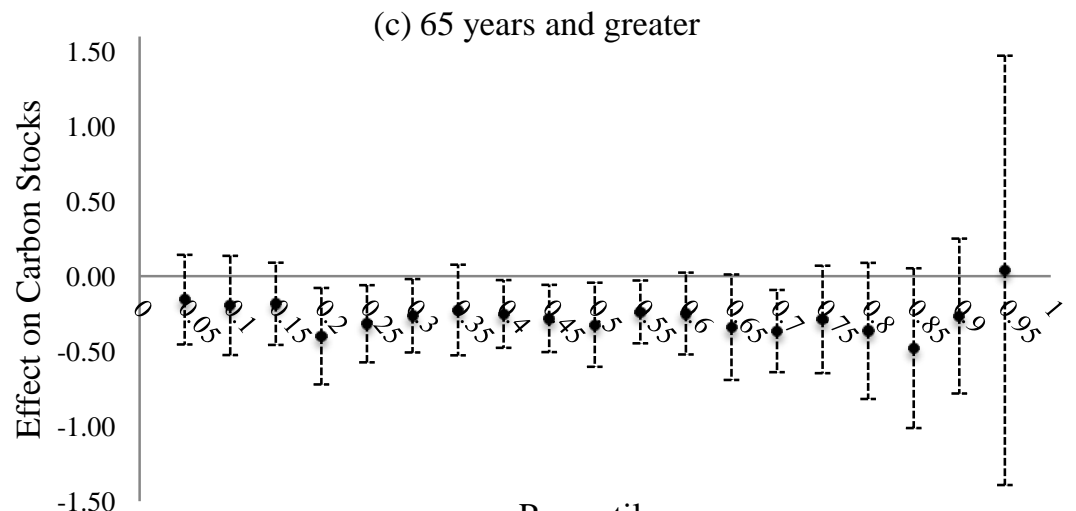

Percentiles 